\title{
Anticipated Barriers to Open Schooling System in Nigeria
}

\author{
Aminu Aliyu Wushishi \\ Faculty of Educational Studies, \\ University Putra Malaysia, Malaysia \\ E-mail: amliyu@yahoo.com
}

Received: 20-02- 2013

Accepted: 02-04-2013

Published: 30-04-2014

doi:10.7575/aiac.ijels.v.2n.2p.85

URL: http://dx.doi.org/10.7575/aiac.ijels.v.2n.2p.85

\begin{abstract}
In an attempt to develop plans for making Education for All a reality, four agencies of the United Nations brought together over 150 governments in 1990 to Jomtien, Thailand, and also in 2000 in Dakar, Senegal, with the aim of making education equally accessible to all. Nigeria is one of the countries that signed the Jomtien declaration in 1990, and one of those with the highest number of out-of-school children in the world with about 10.5 million out-of-school children in 2010 . This figure represents $42 \%$ of its primary age population and 3.6 million more children out of school than ten years ago. Nigeria is now committed towards bridging the gap especially with the attempt towards establishing open schools, but considering the numerous problems confronting the existing public primary and secondary schools and other educational programmes, there are certain barriers that may hinder the successful implementation and smooth running of the proposed open schooling system. This paper examines the anticipated barriers that includes; corruption, lack of consistency in programmes, problem of electricity, lack of access to Internet, lack of fund, inadequate manpower and problem of recognition. For open schooling system to see the light of the day, some recommendations were suggested which, if taken into consideration will be useful to policy makers towards the successful launching and smooth running of the open schools and other laudable educational programmes in Nigeria.
\end{abstract}

Key words: Open Schooling System, Open and Distance Learning

\section{Introduction}

Considering the importance of education in Nigeria for national development, there is no doubt that the sector is greatly expanding and is becoming one of the greatest social services in the country. The sector is fast growing and the huge resources invested can practically be observed on the proliferation of schools and the increase in students' enrolment. Nigeria as every nation, world over, invests in education because of the tremendous benefits to individuals, organisations and the society in general (Yusuf, 2006).

Education is a universal phenomenon which allows all human societies to develop the requisite knowledge, experience and skills for their self-preservation and growth, this implies that education is an integral component of the process of socialization and its nature and scope is suitable to every society relatively to its state of development. One may further argue that education develops individual mentally, emotionally and socially, giving him a sense of self-esteem, a sense of worth and self-respect necessary to free him from the grip of poverty by acquiring the necessary competence, abilities and skills to work in all spheres of the economy.

Therefore, providing education for all to millions of children has been one of the struggles between countries in the world, which resulted to the coming together of Governments of over 150 countries in 1990 at Jumtien, Thailand and ten years later in Dakar, all with the aim of providing various means through which education will be accessible for all irrespective of gender, religion or ethnic background.

\section{A Brief Outlook on Education in Nigeria}

Before the introduction of western education in Nigeria, history has revealed that Nigerians had their traditional or indigenous system of education which was tied to the peoples' occupations, religious practices and other aspect of cultures. In the southern part of Nigeria whose people are predominantly Christians, the traditional education was functional and participatory as the child and adolescent were involved in the practice of farming, trading, craftwork, cooking, sweeping, proverbs, morale uprightness and traditional values (Fafunwa 1995).

In the Northern part of Nigeria which is predominantly inhabited by Muslim, their educational system was slightly different because of their contact with some Arabian territories. Two types of schools were operated namely: Makarantan Allo (Slate School) and Makarantan Ilmi (Advanced School). The Islamic system of education was aimed at providing a balanced development of the individual and the society. It also provided spiritual and moral training and encouraged the acquisition of knowledge and skills which could facilitate worldly/material pursuit (Usman, 2008).

The introduction of western form of education in Nigeria was spearheaded by Rev. Thomas Birch freeman assisted by William De Graft. They launched the campaign in Badagry, Lagos in September 1842. Those that followed later were 
Church Missionary Society (CMS), the Roman Catholic Mission (RCM), and Church of Scotland. The Missionaries established schools in areas such as Lagos, Badagry, Abeokuta, Onitsha and Calabar (Fafunwa 1995).

The colonial administrators adopted British form of education in Nigeria, they introduced the primary, secondary, sixth form and higher education. Although, after the independence in 1960, Policy makers discovered that this system of education did not meet the aspiration of Nigerians so the 6-3-3-4 educational policy was introduced in 1977.

From independence to date Nigerian educational system has witnessed a lot of transformations, so many laws were promulgated with the aim of making the system relevant and functional. Such laws include: Education edicts of 19661979, the educational laws of 1979-1983, the education edicts of 1983-1999 and the education laws of 1999-2004 (Ezikiel-hart 2011).

Constitutionally, both Federal and State governments legislate on the planning, organization and management of education. Primary education, secondary education, adult and non-formal education are managed by the local government authorities and the states. The Federal government is responsible for policy making and the enforcement of standards at the primary and secondary levels but also owns and manages many tertiary institutions (Theobald et al., 2007).

With the independence of 1960, many primary and secondary schools were established across every region in the country. At present there are more than 50,700 primary schools as well as 10,349 secondary schools in Nigeria, the school enrolment was reported as 22.3 million for primary schools and 6.4 million for secondary schools (Federal Ministry of Education, 2005).

\section{The Need for Open Schooling System in Nigeria}

The idea of open schooling system has yielded fruitful results in some developing countries. In India for example, the National open school was established in 1989. As at present the country has the largest open schooling system in the World, with more than 1000 study centers located in the territory of India. Its client groups include the girls, the women, the Scheduled Castes, the Scheduled Tribes, the rural people, the urban poor, the unemployed, the partly employed, the under employed, the young, the adult, and the partially handicapped, the system has cumulative enrolment exceeding over half a million students (Ambasht, 2012).

Other Countries that benefitted from open schooling system include Botswana, Namibia Trinidad and Tobago etc. Open and Distance education is not new in Nigeria, it has been in practice since 1976 especially with the establishment of National Teachers' Institute, Kaduna by the Federal Government of Nigeria with the aim of producing qualified teachers needed to meet the requirements of the then Universal Primary Education (UPE). The Institute was charged with the responsibility of providing courses of instruction leading to the development, up-grading, and certification of teachers as specified in the relevant syllabus using distance education techniques. Thus NTI was the first institution formally established in Nigeria to offer courses via ODL methods (Ojo, 2006).

The National Open University was established in 1983, but was suspended in 1984 by the then military government. In 2002 the National Open University (NOUN) was re-established by the Obasanjo Administration, with its headquarters in Lagos. The NOUN has a campus in Kaduna, an office Annex in Abuja, and 36 study centres scattered all over the country. It has the aim of ensuring equity and equality of opportunities in education specifically in university education, and providing a wider access to education generally but specifically university education in Nigeria (NOUN 2004).

There are other institutions of learning that also provide distance education programme which make it easier for students to obtain qualifications ranging from Bachelor degrees, Diplomas and Nigeria Certificate of Education (NCE), but the programmes are so expensive that not all students can enrol in them, and none of the institutions offers a programme to cater for those that were unable to complete their secondary education.

There is an urgent need for open schooling system in Nigeria, for the fact that the rate of illiteracy and number of children out-of-school is alarming. There were 17 countries with more than 500,000 out-of-school children in 2009, and nine of these countries are located in sub-Saharan Africa. Nigeria alone has almost 9 million out-of-school children or $37 \%$ of its primary school-age population in 2007. Ethiopia had the second highest number of out-of-school children in the region with 2 million in 2009 (UNESCO Institute of statistics, 2009).

Furthermore, the Nigerian Punch Newspaper reported that about 10 million children of school age are out of school in Nigeria, the paper broke down the figure as follows: about 4.7 million were of primary school age, while 5.3 million were of secondary school age. 62 per cent of the children out of school were girls while the remaining 38 per cent were boys (Punch News Paper, $25^{\text {th }}$ march 2008, pg. 14).

Luffman (2012) revealed that Nigeria being the country with the largest population on African continent, the Country alone had 10.5 million out-of-school children in 2010 . This represented $42 \%$ of its primary age population and 3.6 million more children out of school than ten years ago.

Alechenu (2012) attributes most of the nation's social vices such as: prostitution, child trafficking, the armed struggle in the Niger Delta, and the current Boko Haram insurgency in Northern Nigeria, to lack of literacy. Majority of the youth partaking in most of this unwanted acts, are those that are either school drop outs or couldn't get access to school at all.

Nigeria needs open schooling system so as to cater for the high number of out-of-school children, reduce the number of drop outs, and make secondary education accessible for those who for one reason or the other could not attend regular school. 
In fact the goal of Nigeria for meeting its target of Education For All by 2015 may be far from being achieved, although there is a plan already by the Federal Government of Nigeria to provide educational opportunities for children, youth and young adults whose learning needs are not being met by formal conventional schools and complement conventional schooling in the significant reduction and eradication of gender, regional and social inequalities in education through the Open Schooling System.

According to Gidado, Alabi \& Bakri (2008) the aim of the open Schooling system is to explore, develop and establish a wide range of educational courses at post-literacy and pre-tertiary level and to set up effective Open and Distance Learning structures and systems to make those courses available throughout Nigeria to children, young people and adults not currently reached by formal or non-formal education. It will also explore all possible ways to assist, support and expand efforts to significantly raise transition rates from Primary to Junior Secondary School; and provide basic education to out-of-school children and youths, illiterate adults, primary and secondary school drop-outs, marginalized groups such as migrant groups, the girl-child and women.

Gidado et al (2008) further explained that the proposed open school system will have study centres across the country and to efficiently promote the administration of the programme each and every state will have an office while the Zonal and National offices will serve as centres for co-ordination.

Although not all courses will be taught at the school level but based on the proposed pilot test, basic and secondary education will be for adolescent girls and young women who have become early school leavers. Technical/vocational education combined with remedial formal education will be for young men/adolescent boys while continuing education for adults at post-literacy level, and apprentice teachers in nomadic schools.

The programme will target out-of-school youths and adults who can be considered as early leavers, but not pre-literates men and women, specifically primary school drop-outs: graduates of primary schools who could not transit to JSS, graduates of JSS who due to lack of places could not transit to SSS, secondary school dropouts, and marginalized groups such as migrant groups and women. The age bracket will be about between 15 and 25 years.

\section{Barriers to Open Schooling}

In spite of the curiosity and enthusiasm to establish the Open schools in Nigeria, certain barriers may impede the successful implementation and smooth running of the programme, considering how other educational programmes suffered from one obstacle to the other. The anticipated problems are discussed below

\subsection{Corruption}

This is one of the greatest problems destabilising the entire Nigerian educational system. Several efforts by the government to run a laudable educational programmes but collapsed as a result of the corrupt nature of those in charge of the programme. For example, few months ago, government launched the integration of Quranic schools with the western schools. A system where the Almajiris (Quranic Students) will learn western type of education alongside with their Quranic education, but in less than one year a lot of complains related to corruption have started emanating. In fact, money earmarked to build classrooms and hostels in some selected states for pilot test, was diverted by few individuals in charge. If strict measures are not taken, the open schooling system may suffer the same routine habits which will make it difficult for the programme to see the light of the day.

\subsection{Lack of Consistence in programmes}

It is a known fact in Nigeria that as government changes almost all programmes changes as well, no matter how good a programme is, the succeeding government may hardly continue with it because according to them the credit will be accorded to their predecessor who launched it. Open schooling system may likely be affected by frequent changes in educational policies particularly if the subsequent government is not interested in the programme, which is very common with our leaders.

\subsection{Problem of Electricity}

As other nations of the world tackled the issue of electricity supply, in Nigerians it is still an issue. The country is unable to tackle insufficient power supply hence the megawatt generated is still inadequate. Open schooling system can hardly be successful without adequate power supply. Adequate power will facilitate communication and the use of electronic device such as computers, television, radio, etc. which are the vital components in open schools.

\subsection{Lack of access to Internet}

The internet has become a good educational tool that ease and facilitate learning but is very expensive in Nigeria, not only for the citizens but even some institutions of higher learning can hardly afford it, some even suspend their monthly subscriptions to the service providers because they could not afford to cope with the cost. World Bank report (2005) stated that most of the less developed countries in Africa do not have access to the internet, which will add to their slow development and this exacerbated by poor telecommunications infrastructures and low teledensity. Lack of internet access may give open school in Nigeria a big blow, because the rate at which the programme will take place may be slow and considering the population of out-of-school children in Nigeria, there is the need to have facilities on ground that will speed the take-off so as to cover a lot of target population.

\subsection{Inadequate funding}

A lot of educational programmes in Nigeria suffer from inadequate funding from government which results in low standard and failure to achieve the specified aims and objectives of the programme as a result of lack of qualified 
teachers/resources persons and lack of facilities. This can also be observed in the budget allocation to education which, in 2012 the sector received only $8.43 \%$ of the total budget, although, the allocation increased to $8.67 \%$ in the 2013 proposed budget (Federal Ministry of Finance 2012). This is contrary to UNESCO standard of allocating 26\% of the total budget to education. Open schooling system as other practiced educational systems in Nigeria may encounter insufficient funding considering the kind of government in Nigeria who are not willing to properly invest in Education.

\subsection{Poor Man power to handle the programme}

In Nigeria teaching profession is considered as the least job and is no longer attracting hardworking and talented individuals. People prefer other lucrative jobs where the pay package is attractive. Open schooling system would be confronted with the crisis of inadequate man power, because nobody will be willing to stay in a system where the earning may not be attractive, only those with no alternative or who term teaching to be as their stepping stone will accept to become teachers/facilitators in the programme.

\subsection{Problem of recognition}

Another problem that is likely to confront the Open schooling system in Nigeria is the issue of recognition. Many sectors may not recognise their products and this will pose a challenge to them at the labour market. Some institutions will also doubt the credibility of their certificates, as the case with the graduates of National Open University of Nigeria. In fact, some institutions don't recognised certificates of Open University for admission while some universities discourage their staff from attending such courses.

\section{Recommendations}

Based on the observed anticipated barriers that may hinder the success of the proposed open schools in Nigeria, this paper itemised some recommendations that could serve as a way out:

1. For open schools to succeed in Nigeria, certain measures need to be taken particularly in appointing those that will champion the implementation of the programme. Government must choose credible, honest and sincere people whose characters are not questionable. This will help in making a solid foundation for the programme.

2. Government should enact a law regarding open schools as so to make it difficult to be scrapped by any succeeding government.

3. The federal government should improve the condition of power supply through other means of power generation such as: solar system, wind mills or an oil based power generating stations.

4. Having access to internet has a lot of benefits, particularly to a programme like open schooling system. It will improve the research trends of the facilitators by updating them with the new ideas in the world, and it will also facilitate learning among students. Therefore, government should make internet accessible and affordable to all open schools.

5. Government should earmark certain amount of money in her yearly budget to all open schools and also seek for assistance from International Organizations.

6. Apart from salaries, additional incentives should be given to facilitators/teachers partaking in the programme so as to attract best brain and hardworking staff.

7. Government should employ graduates of the programme and appeal with other organisations to do so in order to tackle the issue of recognition.

\section{Conclusion}

There is no doubt that many developing nations were able to reduce the rate of their out-of-school children through the provision of open schooling system. If Nigeria were to be committed and faithfully focus on establishing open schools in different parts of the country, the high rate of their out-of -school children will be reduced and their target of providing Education for All may be actualised, although the target of making it possible by 2015 is far from reality, but it may be achieved in some years to come.

\section{References}

Alechenu J (2012). Nigeria still in throes of illiteracy The Punch $9^{\text {th }}$ September 2012

Ambasht N.K (2012). Open schooling in India: A challenge to technologies for learning and training. Retrieved $4^{\text {th }}$ December 2012 from www.col.org

Ambe-Uva, T. N., \& Island, V. (2006). National Open University of Nigeria (NOUN): A Historical Perspective and Challenges. Journal of Historical Science in Education, 2(2), 76-91.

Ezekiel-hart, J. (2011). Reflections on Politics and Policies of Education for Vision 20: 2020. European journal of educational studies, 3, 2 .

Fafunwa, A.B., (1995). History of Education in Nigeria. NPS Educational Publishers Ltd., Trust House: Ibadan.

Federal Ministry of Education (2005). Education sector analysis

Federal ministry of finance (2012). Budget of the Federal Republic of Nigeria 
Gidado. T.A, Alabi, T., \& Bakri, S. G. (2008). The Need for Open Schooling in Nigeria. Commonwealth of Learning and the Caribbean Consortium.

Luffman L (2012). Too many children out of school in Nigeria and across the world SOS children Terrington House Cambridge

National Open University of Nigeria (NOUN) Aims and Objectives, retrieved $3^{\text {rd }}$ December 2012 from www.noun.edu.ng

Ojo, D. O., \& Olakulehin, F. K. (2006). Attitudes and perceptions of students to open and distance learning in Nigeria. The International Review of Research in Open and Distance Learning, 7(1).

Punch News paper $25^{\text {th }}$ March 2008 pg. 14

Theobald D et al (2007). Nigeria country case study: Country profile prepared for the education for all global monitoring report 2008, Education for All by 2015: Will we make it. Paris, UNESCO Retrieved December, 10, 2012.

UNESCO Institute of statistics (2009). Out-of-school children, retrieved $3{ }^{\text {rd }}$ December 2012 from www.uis.unesco.org

Usman, M.T(2008). Colonial state and the underdevelopment of education in Muslim Emirates in Northern Nigeria in Education and Development in Northern Nigeria by AS Okigbile et al (eds) Smartprint pub. Jos Nigeria.

World Bank (2005). Draft report: Financing information and communication infrastructure needs in the developing world retrieved $2^{\text {nd }}$ December 2012 from www.info.worldbank.org

Yusuf, M. O. (2006). Problems and prospects of open and distance education in Nigeria. Turkish Online Journal of Distance Education, 7(1), 22-29. 